JOURNAL OF MANAGEMENT OF AQUATIC RESOURCES.

Volume 1, Nomor 1, Tahun 2012, Halaman 1-6

Online di : http://ejournal-s1.undip.ac.id/index.php/maquares

\title{
KEPEDULIAN MASYARAKAT DAN EFEKTIVITAS KAMPANYE ZONA INTI DI TAMAN NASIONAL KARIMUNJAWA
}

\author{
Bima Tri Widyatmoko, Frida Purwanti, Agung Suryanto*)
}

Jurusan Perikanan, Fakultas Perikanan dan Ilmu Kelautan, Universitas Diponegoro

Jl. Prof. H. Soedharto, SH, Tembalang Semarang. 50275 Telp/Fax (024) 7474698

\begin{abstract}
Abstrak
Taman Nasional didefinisikan sebagai kawasan pelestarian alam yang mempunyai ekosistem asli, dikelola dengan sistem zonasi, dan dimanfaatkan untuk tujuan penelitian. Persepsi yang salah mengenai pemanfaatan sumberdaya oleh masyarakat akan menjadi pemicu kerusakan ekosistem. Penelitian ini dimaksudkan untuk mengetahui kegiatan penangkapan masyarakat dan kepedulian masyarakat terhadap keberadaan Zona Inti, sekaligus mengetahui efektivitas kampanye dalam hal media komunikasi untuk membantu pemahaman masyarakat terhadap keberadaan Zona Inti. Metode penelitian dilakukan dengan Observasi Lapangan, dengan pengambilan data yang dilakukan dengan melakukan jajak pendapat kepada masyarakat dengan acuan pertanyaan dari kuisioner. Kuisioner yang digunakan dalam kampanye Zona Inti adalah menurut Strategic Plan RARE Coral Triangle 2010-2011 Marine Thematic Cohort. Gambaran kuisioner yang akan diberikan meliputi Profil responden, Kegiatan penangkapan dan lokasi kegiatan penangkapan, Pengetahuan masyarakat mengenai Zona Inti, dan Efektivitas media komunikasi yang digunakan dalam kampanye Zona Inti. Berdasarkan penelitian diketahui bahwa penangkapan dilakukan dalam kegiatan ramah lingkungan karena $46 \%$ menggunakan pancing tonda. Sebesar $76 \%$ mengakui perbedaan jarak penangkapan yang semakin jauh. Pengetahuan lokasi Zona Inti mengalami peningkatan dan kesediaan menjadi kelompok partisipatif dalam pengawasan Zona Inti sebesar 68,4 \%. Efektivitas kampanye terlihat dari penggunaan SMS (Short Message Service) yang menjadi media komunikasi dua arah. Hal ini yang menjadikan SMS sebagai media komunikasi yang efektif dalam penyampaian pesan-pesan kampanye.
\end{abstract}

Kata Kunci : Kepedulian, Masyarakat, Taman Nasional Karimunjawa, Kampanye Zona Inti

\begin{abstract}
National Parks are defined as having a nature conservation area of native ecosystems, managed by the zoning system, and used for research purposes. Karimunjawa community that relies on the natural result will be a problem that would arise if there is no clarity and knowledge on natural resources will be exhausted. This study aimed to determine the incidence of community and public awareness of the existence of the Core Zone, as well as the effectiveness of media campaigns in terms of communication to help people's understanding of the existence of the Core Zone. Data is collected by the distribution of questionnaires. The questionnaire used in the Core Zone campaign is under the Strategic Plan 2010-2011 RARE Coral Triangle Marine Thematic Cohort. Overview will be given a questionnaire that includes profiles of respondents, fishing activities and the location of fishing activities, public knowledge about the core zone, and the effectiveness of the communication media used in the Core Zone campaign. Based on the research note that the arrests were made in an environmentally friendly activity because $46 \%$ using a fishing rod Tonda. $76 \%$ recognize the difference that the farther the distance catching. Knowledge of the location of the Core Zone and the willingness to increase participation in the surveillance group core zone of 68.4\%. The effectiveness of the campaign can be seen from the use of SMS (Short Message Service) is a two-way communication media. This is what makes SMS as effecttive at communications media in the delivery of campaign messages.
\end{abstract}

Keywords: Caring, Community, National Park Karimunjawa, Core Zone Campaign

\footnotetext{
${ }^{*}$ Penulis Penanggung Jawab
} 


\section{Pendahuluan}

Menurut Undang Undang No. 5 tahun 1990 tentang Konservasi Sumberdaya Alam Hayati dan Ekosistem menyatakan Taman Nasional merupakan kawasan pelestarian alam yang mempunyai ekosistem asli, dikelola melalui sistem zonasi, dan dimanfaatkan untuk tujuan penelitian, ilmu pengetahuan, pendidikan, penunjang budidaya, serta pariwisata dan rekreasi. Jadi konsep penetapan Taman Nasional sebagai kawasan konservasi sangat ideal dengan tiga fungsi utamanya yaitu sebagai perlindungan sistem penyangga kehidupan, pengawetan keanekaragaman hayati dan sumber plasma nutfah serta pemanfaatan yang lestari keanekaragaman hayati dan ekosistemnya, namun bukan berarti tidak menghadapi permasalahan. Sejak awal pembentukannya, pemerintah terus mencari konsep pengelolaan Taman Nasional yang ideal atau yang cocok dengan kondisi biofisik, sosial, ekonomi dan budaya setempat serta dapat mengkoordinir semua kepentingan.

Balai Taman Nasional Karimunjawa maupun WCS telah menemukan bahwa kesadaran masyarakat tentang masalah penangkapan ikan berlebih masih terlalu rendah untuk penegakkan larangan penangkapan ikan secara total. Tantangannya sekarang adalah meningkatkan penerimaan masyarakat atas zonasi (kawasan-kawasan larang-tangkap yang ada), sekaligus menguatkan pengawasan formal dan pengawasan berbasiskan kemasyarakatan atas kawasankawasan tersebut untuk menegakkan peraturan-peraturan yang ada. Maka dari itu diperlukan adanya penanaman pemahaman kepada masyarakat Karimunjawa pada khususnya untuk ikut berperan aktif dalam menjaga lokasi Zona Inti atau lokasi-lokasi larang tangkap yang telah ditentukan.

Masyarakat Karimunjawa yang semakin menggantungkan hidupnya dari kekayaan hayati yang diberikan alam tanpa mempedulikan imbas yang akan didapatkan suatu hari nanti, yaitu berkurangnya stok ikan yang ada dapat menjadi bom waktu terhadap kekayaan hayati Karimunjawa. Pembagian Zonasi yang dilakukan pihak Balai Taman Nasional Karimunjawa seakan tidak dapat menggapai tujuan sebagaimana mestinya. Pihak Balai Taman Nasional Karimunjawa telah bekerjasama dengan pihak RARE dan WCS sebagai pihak swasta yang berfokus pada konservasi untuk melaksanakan kampanye dengan tujuan meningkatkan pengetahuan masyarakat Karimunjawa terhadap Zona Inti.

\section{Metodologi Penelitian}

\section{A. Metode Penelitian}

Pencapaian tujuan penelitian yaitu mengkaji secara Observasi Lapangan dalam kondisi masyarakat mengenai keberadaan Zona Inti di Taman Nasional Karimunjawa, metode yang digunakan dalam penelitian ini adalah metode analisa secara deskriptif dengan pendekatan kualitatif dan kuantitatif.

\section{B. Metode Pengambilan Data}

Pengambilan data mengenai penelitian Kepedulian masyarakat Karimunjawa terhadap Zona Inti di Taman Nasional Karimunjawa adalah berupa pembagian kuisioner kepada masyarakat. Pembuatan kuisioner yang digunakan dalam kampanye Zona Inti guna memenuhi data-data yang diinginkan adalah menurut Strategic Plan RARE Coral Triangle 2010-2011 Marine Thematic Cohort. Gambaran kuisioner yang akan diberikan kepada Responden meliputi :

1. Profil responden;

2. Kegiatan penangkapan dan lokasi kegiatan penangkapan;

3. Pengetahuan masyarakat mengenai Zona Inti; dan

4. Efektivitas media komunikasi yang digunakan dalam kampanye Zona Inti.

Melalui ketetapan dari Strategic Plan RARE Coral Triangle 2010-2011 Marine Thematic Cohort, serta berdasarkan proporsi jumlah responden pada tiap desa dapat dilihat pada tabel di atas, dengan total responden nelayan sejumlah 334 responden dan responden non nelayan sejumlah 323 responden. Secara keseluruhan jumlah kuisioner yang digunakan berjumlah 657 kuisioner. Pengambilan data berupa Jajak Pendapat kepada para responden dilakukan oleh enumerator dengan jumlah 16 orang. Enumerator disini berfungsi sebagai eksekutor lapangan dalam proses wawancara Jajak Pendapat kepada responden, dari hasil wawancara dari para enumerator tersebutlah didapatkan data-data yang dibutuhkan dalam menentukan hasil yang diperoleh selama Kampanye Zona Inti. Enumerator yang menjadi pewawancara lapangan adalah tim gabungan dari mahasiswa dan masyarakat lokal Karimunjawa sendiri. Dari satu tim yang terdiri dari beberapa enumerator tersebut diketuai oleh seorang supervisor yang bertanggung jawab atas kelancaran pada saat di proses wawancara dan tersampaikannya kuisioner tersebut kepada responden. Berikut untuk lebih jelasnya gambaran mengenai penyebaran kuisioner dari tiga desa. Penyebaran kuisioner pada tiga desa meliputi Desa Karimunjawa, Desa Kemujan, dan Desa Parang.

\section{Metode Penentuan Lokasi Sampling}

Metode analisis data dalam penelitian ini menggunakan Survey Pro 30 dengan serial number SP3-1-YGH-KF2 secara ijin penggunaan Software diberikan oleh Yusuf Syaifudin selaku Campaign Manager dalam program RARE "Pride Campaign" di Taman Nasional Karimunjawa. Analisis hasil sebagai pendataan kuantitatif dalam Survey Pro 30 dapat dijabarkan menjadi tiga bentuk data output yaitu antara lain adalah data tabel (tersaji pada Lampiran 4), custom report (tersaji pada Lampiran 5), dan executive summary (tersaji pada Lampiran 6). Software Survey Pro 30 dalam pendataan kuantitatif tersebut berfungsi untuk mempermudah dan mempercepat proses pendataan tanpa mengesampingkan tingkat ketelitian data. Survey Pro 30 diciptakan sebagai alat bantu untuk mengukur suatu pencapaian dari program yang dijalankan. Gambaran kinerja analisis data menggunakan Survey Pro 30 adalah sebagai berikut, setelah didapatkannya data lapangan dari kuisioner Jajak Pendapat kepada masyarakat setelah itu data kuisioner masuk dalam proses 
penginputan data (Answer Entry) ke dalam Survey Pro 30. Data kuisioner yang sudah masuk tersebut nantinya akan secara otomotis dianalisis oleh sistem formula Survey Pro 30 dan akan keluar menjadi berupa data grafis, tabel, dan presentase dalam tiga jenis data antara lain Data Tabel, Custom Report, dan Executive Summary sebagai output data yang didapatkan.

\section{Hasil dan Pembahasan \\ Profil Responden}

Penduduk Karimunjawa tersusun atas beberapa etnis asal yaitu Jawa, Madura dan Sulawesi dengan suku Jawa, Madura, Bugis, Mandar, Bajau, Munak, dan Luwu. Mayoritas penduduk Karimunjawa berasal dari Jawa sehingga budaya Jawa mendominasi kebudayaan lokal, namun walau demikian kebudayaan lain nampak nyata pada kehidupan sehari-hari misalnya saja terlihat pada bentuk rumah penduduk Bugis di Pulau Kemujan.

Penduduk Karimunjawa banyak terdapat di empat pulau utama yaitu Pulau Karimunjawa sebagai pusat pemerintahan, 3 Pulau lain yaitu Pulau Kemujan, Pulau Parang, dan Pulau Nyamuk. Empat pulau tersebut yang menjadi sasaran utama persebaran kuisioner yang ditujukan kepada masyarakat Karimunjawa.

\section{Kegiatan Penangkapan Nelayan Karimunjawa}

Pada faktanya sebagian besar penduduk Karimunjawa peduli akan kawasan Zona Inti di kawasan Taman Nasional Karimunjawa. Hal ini didasarkan pada presentase yang didapatkan setelah dilakukan wawancara dengan masyarakat lokal Karimunjawa. Masyarakat yang menyatakan peduli mengenai penangkapan ikan di kawasan Zona Inti sebesar $62 \%$, sebesar $25 \%$ masyarakat menyatakan tidak tertarik pada kawasan Zona Inti, dan masyarakat yang masih belum yakin akan manfaat keberadaan kawasan larang tangkap sebesar $13 \%$.

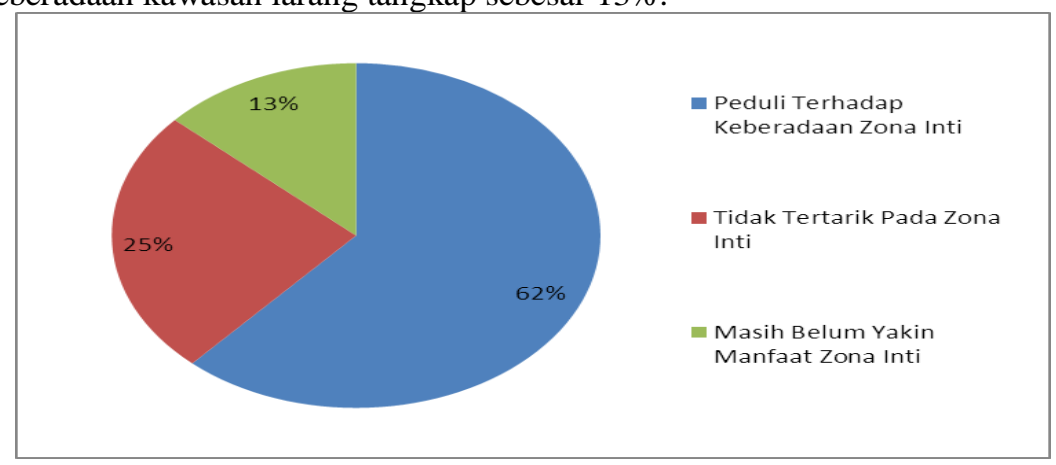

Gambar 1. Kepedulian Masyarakat Mengenai Zona Inti

Masyarakat yang mengaku belum yakin mengenai manfaat ataupun tidak peduli terhadap kawasan larang dikarenakan belum jelasnya manfaat Zona Inti yang mereka dapat secara langsung dari segi perbaikan pendapatan nelayan. Selain itu pengetahuan masyarakat juga masih dianggap kurang mengenai manfaat keberadaan Zona Inti.

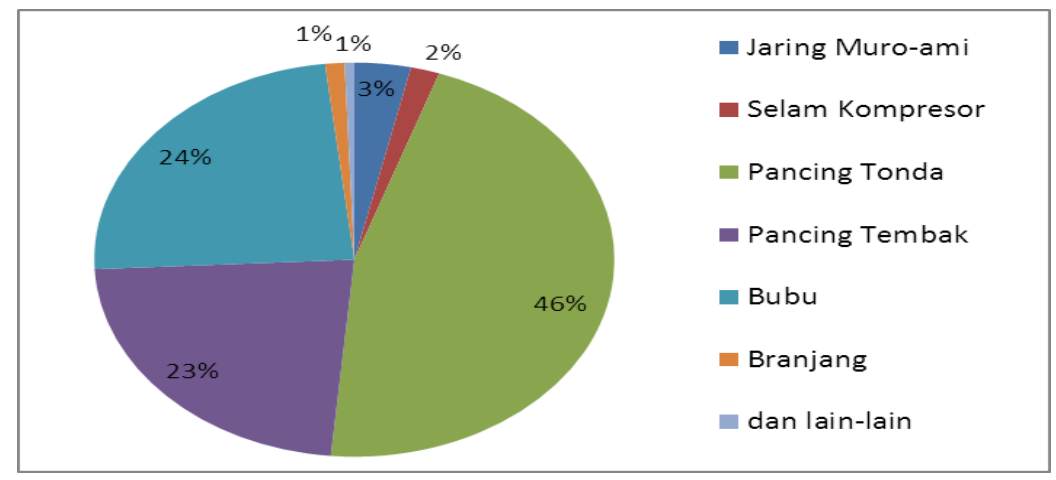

Gambar 2.Alat Tangkap Yang Digunakan Nelayan Karimunjawa

Kepedulian masyarakat lokal Karimunjawa terhadap Zona Inti juga ditandai dengan pemakaian alat tangkap yang ramah lingkungan. Alat tangkap yang digunakan oleh sebanyak 46\% masyarakat adalah Pancing Tonda dan yang kedua sebanyak 24\% masyarakat menyatakan menggunakan Bubu/Trap sebagai alat tangkap. Penggunaan alat tangkap yang ramah lingkungan tersebut yang menjadi bukti nyata kepedulian masyarakat nelayan lokal Karimunjawa terhadap konservasi laut pada umumnya dan keberadaan Zona Inti dengan tujuan sebagai tabungan ikan. Pancing tonda adalah alat penangkap ikan yang terdiri dari seutas tali panjang, mata pancing, dan umpan serta tidak menggunakan pemberat. Pancing ditarik di belakang perahu motor atau kapal yang sedang bergerak. Umpan yang dipakai adalah umpan buatan. Pancing tonda termasuk ke dalam alat penangkap ikan pancing (Tegar Hakim dalam Ayodyoa, 1981).

\section{Kepedulian Masyarakat Terhadap Keberadaan Zona Inti}

Pengetahuan masyarakat Karimunjawa yang berada pada tiga desa terhadap lokasi kawasan Zona Inti menurut naskah penyusun revisi Zonasi terbilang cukup bagus, sebanyak 35\% menjawab dengan benar dan mengetahui keberadaan Zona Inti terdekat dengan lokasi wawancara dan sebanyak $26 \%$ masyarakat menjawab dengan benar lokasi Zona Inti 
walaupun bukan kawasan Zona Inti yang terdekat dengan lokasi saat dilakukan wawancara. Sedangkan apabila dijabarkan kembali menurut tiap desa masing-masing mengenai pengetahuan masyarakatnya terhadap lokasi Zona Inti, masyarakat pada Desa Parang yang masih dapat dikatakan mayoritas belum mengetahui lokasi Zona Inti apabila dibandingkan dengan dua desa lain yaitu Desa Karimunjawa dan Desa Kemujan. Maka dari itu setelah melihat data tersebut perlu ditingkatkan usaha sosialisasi dan informasi mengenai pengetahuan Zona Inti pada masyarakat nelayan maupun non nelayan pada Desa Parang.

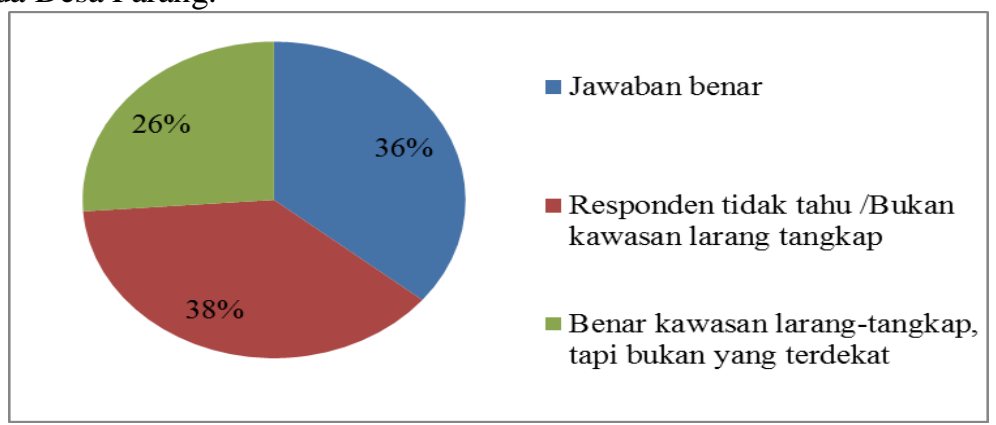

Gambar 3. Pengetahuan Terhadap Lokasi Zona Inti

Secara garis besar apabila dijumlahkan dari jumlah masyarakat yang mengetahui keberadaan Zona Inti dengan tepat sebesar 36\% dan masyarakat yang mengetahui lokasi Zona Inti akan tetapi bukan yang terdekat sebesar $26 \%$ maka setelah digabungkan menjadi satu kelompok masyarakat yang mengetahui lokasi Zona Inti di Taman Nasional Karimunjawa didapatkan presentase masyarakat sebesar 62\%. Apabila dibandingkan pada pendataan yang dilakukan oleh Y. Syaefudin (2010), menyatakan pengetahuan Masyarakat (baik nelayan maupun non nelayan) mengenai letak Zona Inti masih cukup rendah yaitu sebasar 28,6\%. Hal ini menunjukan peningkatan pengetahuan masyarakat mengenai keberadaan Zona Inti yang dimana pada tahun 2010 dapat dikatakan cukup rendah yaitu sebesar 28,6\% menjadi 61\% di tahun 2012.

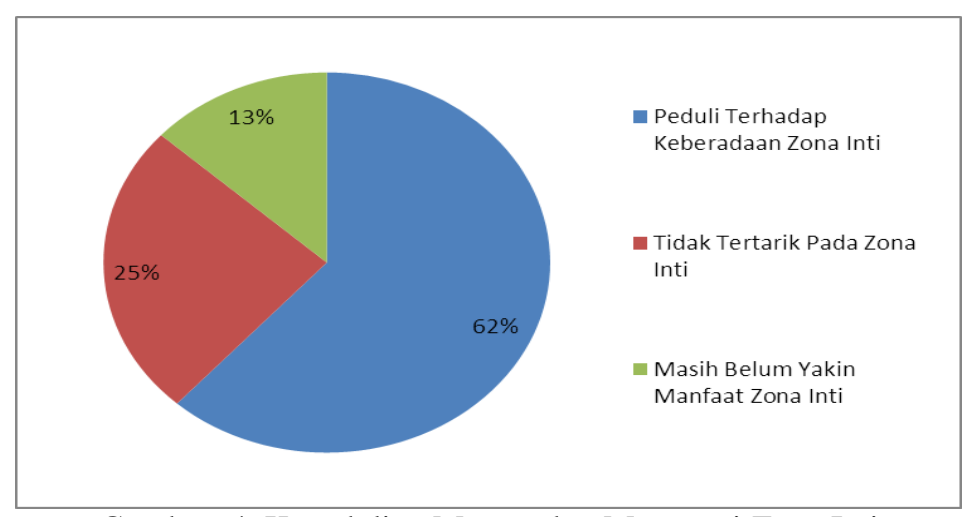

Gambar 4. Kepedulian Masyarakat Mengenai Zona Inti

Dukungan masyarakat Karimunjawa bertambah dengan didapatkan pendataan mengenai kesediaan masyarakat dalam membantu pengawasan bersama Zona Inti sebagai kelompok partisipatif. Masyarakat partisipatif adalah kelompokkelompok masyarakat yang bersedia membantu memaksimalkan kinerja Balai Taman Nasional Karimunjawa dalam pengawasan Zona Inti. Mayoritas masyarakat bersedia menjadi kelompok masyarakat partisipatif pengawasan Zona Inti, hal ini dinyatakan dengan presentase sebesar 68,4 \%. Masyarakat yang menyatakan netral dan akan mengikuti ketentuan yang berlaku dengan presentase sebanyak 24,2\%, masyarakat yang menyatakan netral dan lebih memilih mengikuti kebijakan yang berlaku di sini masuk dalam kelompok masyarakat yang kurang mengerti akan manfaat yang diberikan Zona Inti dan belum munculnya kesadaran tentang peran penting masyarakat. Kelompok masyarakat yang tidak setuju disebutkan dengan presentase sebesar 7,5\%, masyarakat yang menyatakan tidak setuju untuk ikut dalam pengawasan Zona Inti Dikarenakan masyarakat belum mengetahui secara langsung manfaat yang diberikan dengan adanya Zona Inti kepada hasil tangkapan para nelayan Karimunjawa khususnya. Masyarakat lebih menganggap dengan keberadaan Zona Inti lebih mengurangi daya jelajah mereka untuk melakukan kegiatan penangkapan. Kesediaan masyarakat Karimunjawa tersebut yang dapat diartikan sebagai munculnya pengetahuan manfaat dalam kesediaan dalam peran aktif ikut melaksanakan pengawasan Zona Inti. Setelah didapatkan data sebagai berikut diharapkan pemerintah ataupun instansi terkait dapat merangkul Masyarakat Karimunjawa untuk lebih berperan aktif dalam pengawasan Zona Inti bersama sebagai kelompok partisipatif Masyarakat.

\section{Efektivitas Media Komunikasi}

Media komunikasi dalam Kampanye Zona Inti sangat berperan vital sebagai alat penunjang tercapainya pesan tujuan kampanye kepada masyarakat luas dan Karimunjawa pada khususnya. Sukses tidaknya penyampaian pesan kepada masyarakat melalui media komunikasi juga cukup berpengaruh kepada keberhasilan sebuah kampanye. Hal ini dibuktikan dengan sampainya pesan yang diterima masyarakat melalui media komunikasi yang digunakan dalam 
kampanye Zona Inti. Media komunikasi yang digunakan meliputi SMS (Short Message Service), Poster, Kalender, dan Spanduk yang terpasang di warung-warung.

Melalui media komunikasi yang ditujukan masyarakat, tingkat keberhasilan cukup tinggi dibuktikan melalui pendataan kuisioner dengan responden Masyarakat Karimunjawa. Banyak dari masyarakat yang menyatakan melihat dan melakukan interaksi dengan pihak Balai Taman Nasional dengan mengikuti kuis SMS yang diadakan. Pernyataan ini juga ditunjang dengan peningkatan pengetahuan, lokasi, dan manfaat mengenai keberadaan Zona Inti oleh Masyarakat Karimunjawa. Menurut Yusuf Syaifudin (2012), selaku Manager Campaign untuk RARE di Taman Nasional Karimunjawa menyatakan penggunaan media komunikasi sangat efektif apabila dilihat dari presentase tersampaikannya tujuan kampanye Zona Inti melalui berbagai macam media komunikasi yang digunakan. Disamping itu diperkuat dengan peningkatan yang positif meliputi pengetahuan, lokasi Zona Inti, dan manfaat mengenai keberadaan Zona Inti oleh masyarakat Karimunjawa.

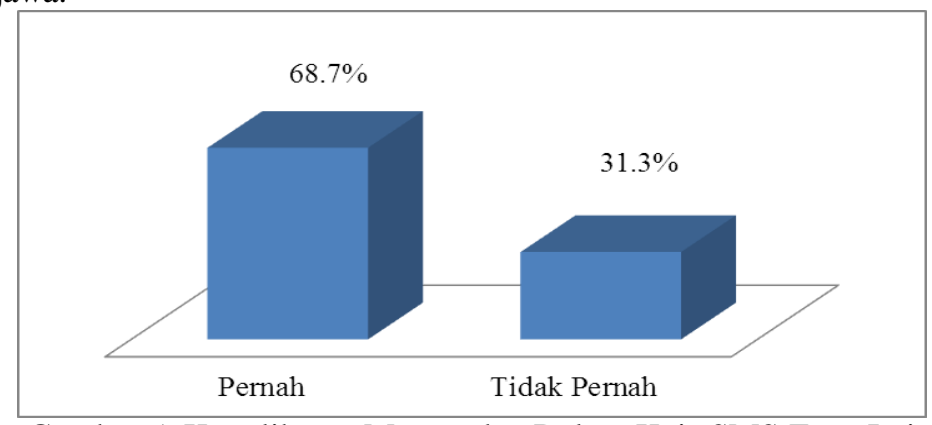

Gambar 5. Keterlibatan Masyarakat Dalam Kuis SMS Zona Inti

Secara keseluruhan media komunikasi yang digunakan, semua media yang digunakan sudah mendapatkan tujuannya agar tersampaikannya pesan-pesan kampanye kepada masyarakat. Dari keseluruhan media komunikasi yang digunakan terdapat satu media komunikasi berupa SMS (Short Message Service) yang mampu memberikan efek komunikasi dua arah antara pihak Balai Taman Nasional dan masyarakat Karimunjawa. Komunikasi dua arah inilah yang sesungguhnya sangat dibutuhkan dalam tujuan meningkatkan pengetahuan masyarakat mengenai Zona Inti, komunikasi dua arah ini dapat dilihat dari banyaknya masyarakat Karimunjawa yang juga bersedia mengikuti kuis SMS yang menyangkut Zona Inti di kawasan Taman Nasional Karimunjawa. Faktor lain yang menjadikan SMS sebagai media komunikasi yang efektif dalam kegiatan kampanye adalah sudah mulai tanggapnya masyarakat Karimunjawa terhadap perkembangan teknologi yang ada sehingga menjadikan Handphone sebagai barang umum yang banyak dimiliki oleh masyarakat. Hal ini yang menjadikan peluang oleh pihak Balai Taman Nasional Karimunjawa untuk menggunakan SMS sebagai salah satu media komunikasi untuk menunjang tersampaikannya pesan-pesan kampanye kepada masyarakat.

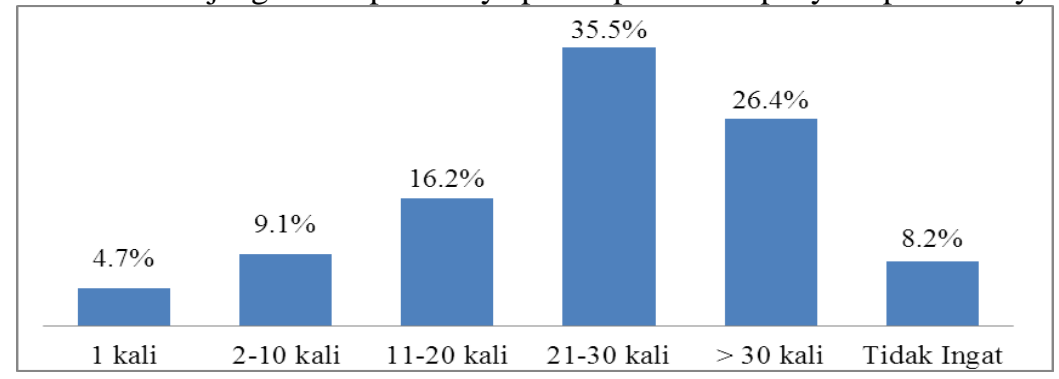

Gambar 6. Interval Penerimaan SMS kepada Masyarakat

\section{Kesimpulan}

Kesimpulan yang didapatkan dari penelitian ini adalah Kegiatan penangkapan yang dilakukan nelayan Karimunjawa termasuk dalam penangkapan ramah lingkungan karena mayoritas nelayan menggunakan pancing tonda dengan presentase sebesar 46\%, pada lokasi penangkapan masyarakat dengan presentase $76 \%$ mengakui jarak penangkapan lebih jauh dibandingkan pada awal karir. Pengetahuan mengenai lokasi Zona Inti masyarakat Desa Parang masih dapat dikatakan kurang mengetahui lokasi Zona Inti apabila dibandingkan masyarakat Desa Karimunjawa dan Desa Kemujan. Kepedulian masyarakat terhadap lokasi Zona Inti cukup tinggi terlihat dari kesediaan masyarakat menjadi kelompok partisipatif membantu pengawasan Zona Inti sebesar 68,4 \%. Efektivitas kampanye terlihat dari penggunaan SMS (Short Message Service) yang dapat menjadi media komunikasi dua arah kepada masyarakat Karimunjawa. Hal ini yang menjadikan SMS sebagai media komunikasi yang efektif dalam penyampaian pesan-pesan kampanye.

\section{Daftar Pustaka}

Peraturan Menteri Kehutanan No.56 tahun 2006 mengenai Pedoman Pembagian Zonasi Pada Taman Nasional 
Prasetia, R., T. Kartawijaya, Ripanto. 2010. Laporan Monitoring. Kajian Tingkat Kepatuhan (Compliance) Nelayan Terhadap Zonasi di Taman Nasional Karimunjawa 2009. Wildlife Conser vation Society-Indonesia Marine Program. Bogor. Indonesia.

Rare 2009. Strategic Plan - RARE - Coral Triangle. 2010-2011 Marine Thematic Cohort. Indonesia - Malaysia - East Timor. Rare, Bogor, Indonesia.

Syaifudin, Y. 2012. Kampanye Bangga Taman Nasional Karimunjawa periode 2010-2012. RARE. Bogor. Indonesia Tegar, H. 2012. www.info.perikanan-kelautan.org diakses 24 Agustus 2012 pukul 21.32 WIB

Undang Undang No.5 tahun 1990 tentang Konservasi Sumberdaya Alam Hayati dan Ekosistem. 